\title{
Generation of thermogenic methane in the Central Alps (Switzerland) during Mid Miocene metamorphism - New insights from paired clumped isotopologues $\left({ }^{13} \mathrm{CH}_{3} \mathrm{D}\right.$ and $\left.{ }^{12} \mathrm{CH}_{2} \mathrm{D}_{2}\right)$
}

Mangenot, $X^{1,3}$. TARANTOla, A. ${ }^{2}$, GiRARD, J.P. ${ }^{3}$, LE V.H. ${ }^{2}$, Mullis, J. ${ }^{4}$, EILER, J.M. ${ }^{1}$

${ }^{1}$ Caltech, Geological and Planetary Sciences (USA)

*xmang@caltech.edu.

${ }^{2}$ Université de Lorraine, CNRS, GeoResssources (France)

${ }^{3}$ Total (France)

${ }^{4}$ Institute of Mineralogy and Petrography (Switzerland)

This paper reports analyses of ancient methane sealed in fluid inclusions of tectonic veins to document a widespread methanogenesis process during the Middle Miocene Alpine compression. The investigated fluid inclusions are dominated by co-genetic $\mathrm{H}_{2} \mathrm{O}$ - and $\mathrm{CH}_{4}$ inclusions. Molecular and isotopic analyses of the $\mathrm{CH}_{4}$ bearing fluid inclusions $\left(\delta^{13} \mathrm{C}, \delta \mathrm{D}, \Delta^{12} \mathrm{CH}_{2} \mathrm{D}_{2}\right.$ and $\left.\Delta^{13} \mathrm{CH}_{3} \mathrm{D}\right)$ indicate than entrapped methane is a dry thermogenic gas $[\mathrm{C} 1 /(\mathrm{C} 2+\mathrm{C} 3)>95 \%]$ generated at very high maturity $\left(\delta^{13} \mathrm{C}=-26 /-30 \%\right.$ and $\delta \mathrm{D}=-126 /-$ $137 \%$ ). This methane preserves internal isotopic equilibrium in $\Delta^{13} \mathrm{CH}_{3} \mathrm{D} / \Delta^{12} \mathrm{CH}_{2} \mathrm{D}_{2}$ space, that translate into temperatures of $243 \pm 18^{\circ} \mathrm{C}\left(\Delta^{13} \mathrm{CH}_{3} \mathrm{D} ; \mathrm{n}=10\right)$ and $216 \pm 14^{\circ} \mathrm{C} \quad\left(\Delta^{12} \mathrm{CH}_{2} \mathrm{D}_{2} ; \quad \mathrm{n}=10\right)$. These "clumping" temperatures agree with the mineral precipitation temperatures derived from FI microthermometry $(\mathrm{Th}=$ $227 / 260^{\circ} \mathrm{C}$ ). Our findings reveal that a significant methanogenesis process occurred during peak metamorphic temperatures (c. 25 to $15 \mathrm{Ma}$ ) from the catagenesis of the surrounding organic-rich flysch (Ro $>4-5 \%$ ). Then, in a subsequent event during the Miocene (c. 17 to $10 \mathrm{Ma}$ ), the nappe structure started to updome and fracture, a process that may have favored significant emission of methane into the atmosphere in a time span overlapping the mid-Miocene climatic optimum event, i.e. a relatively warm period. 